\title{
FROM NEOLIBERAL PRACTICES TO THE PARTICIPATIVE DEMOCRACY OF INTEGRATED URBAN DEVELOPMENT: THE PATH OF RESIDENTIAL HOUSING IN “LIKO-GRAD” KYIV
}

\author{
'Olena DRONOVA, Karina KLYUI, Diana KHOMENKO \\ Taras Shevchenko National University of Kyiv, Ukraine \\ 'olena.dronova@gmail.com
}

\begin{abstract}
Most major cities in Ukraine are experiencing widespread use of neoliberal approaches in urban planning and governance. These approaches are focused on economic priorities and the accumulation of capital by individual government-private coalitions both for new urban projects and practices of modifying urban space in areas of existing development. They ignore the needs of the local people, who, in turn, do not have a deep awareness of their importance and role in making management decisions regarding urban development. Simultaneously with the application of neoliberal urban practices, some integrated urban development projects are being implemented in a number of cities or districts of cities of Ukraine within the framework of international technical assistance and exchange programs. They provide opportunities for all segments of society to understand the consequences of decision-making in a particular area. These efforts increase the importance of this research task which aims to analyze the processes of public participation in urban decision-making and the formation of integration in new local and multi-family residential housing development in Kyiv where there is no involvement in international cooperation in integrated urban development. The authors consider these issues using the example of the new "Liko-Grad" residential development. Our working hypothesis examines the dominance of neoliberal urban practices prevailing in such areas. The results of a survey of residents, conducted in 2018 and 2020, raises issues related to integrated development, the inclusiveness of urban space and the extent of involvement of residents in decision-making related to housing and urban landscape. These results as well as expert analysis of open-source data about the development, help to understand that the residential complex "Liko-Grad" which was built by a developer based on neoliberal management decisions. The potential residents were unable to participate in the decision-making process on building and planning the infrastructure. Today, in the process of community formation, residents reveal they are somewhat satisfied with the level of landscaping and are taking the first steps to address certain issues as evidenced by their active participation in social networks and some non-systematic landscaping activities and other small projects within the public budget. The survey also revealed low levels of job opportunities, social infrastructure, poor street infrastructure, and public transport needs as well as a low level of urban inclusion. These results, together with the lack of business activities and function, do not enable the residents of "Liko-Grad" to become a multifunctional urban space according to the integrated approaches designed for this space. We conclude that the path of Ukrainian cities to participatory democracy is just emerging; it requires a deep awareness of local communities of its importance of such efforts and also incorporating management decisions which affect the interests of all residents.
\end{abstract}

Key words: neoliberal urban practices, integrated urban development, public participation, Kyiv.

DOI: https://doi.org/10.17721/2413-7154/2021.85.72-85

UDC: 911.3:3.316

Received: November 24, 2020.

Accepted: January 25, 2021.

\section{ВІД ПРАКТИК НЕОЛІБЕРАЛІЗМУ ДО ПАРТИСИПАТИВНОЇ ДЕМОКРАТІЇ ІНТЕГРОВАНОГО МІСЬКОГО РОЗВИТКУ: ШЛЯХ МІКРОРАЙОНУ ЖК “ЛІКО-ГРАД", КИЇВ}

\author{
'Олена ДРОНОВА, Каріна КЛюЙ, Діана ХОМЕНКО
}

Київський начіональний університет імені Тараса Шевченка, Україна

'olena.dronova@gmail.com

Анотація: Більшість міст-мільйонерів України переживають часи широкого застосування неоліберальних підходів у системі міського планування та управління. Ці підходи орієнтовані на економічні пріоритети та накопичення капіталу окремими владно-приватними коаліціями стосуються як нових містобудівних проектів так і практик модифікування міського простору у зонах існуючої забудови. Вони ігнорують потреби місцевого населення, яке, у свою чергу, не має глибоко сформованого усвідомлення свого значення і ролі щодо прийняття управлінських рішень у сфері міського розвитку. Паралельно з застосуванням неоліберальних міських практик, у окремих містах чи районах міст України, починають реалізовуватися проекти інтегрованого міського розвитку в рамках міжнародних програм технічної допомоги та обміну досвідом, що передбачають систему прийняття рішень, яка забезпечує врахування думок всіх прошарків суспільства та розуміння наслідків прийняття рішень в конкретній сфері з огляду на інші сфери, що піднімає значення даного дослідження. Метою статті $\epsilon$ аналіз процесів участі громадськості у прийнятті містобудівних рішень та формуванні інтегрованості у місцях нової забудови Києва на локальному рівні, де не відбувається залучення до міжнародної співпраці у сфері інтегрованого розвитку, на прикладі нового житлового масиву «Ліко-Град», оскільки існує припущення, що в таких районах переважає домінування неоліберальних міських практик. Анкетування мешканців, яке провели автори у 2018 і 2020 рр., піднімає питання, що стосуються інтегрованого розвитку, інклюзивності простору та залучення мешканців до вирішення питань розвитку житлового масиву. Результати опитування, а також експертний аналіз даних відкритих 
джерел допоміг з'ясувати, що ЖК «Ліко-Град» було побудованодевелопером на основі застосування неоліберальних управлінських рішень, потенційні мешканці не мали можливості брати участь у прийнятті рішень щодо організації забудови та планування об'єктів інфраструктури. На сьогодні, у процесі формування громади, мешканці певною мірою задоволенірівнем благоустрою мікрорайону і роблять перші кроки щодо вирішення окремих питань, про що свідчить їх активна участь у соціальних мережах та окремі не систематичні заходи з благоустрою території, малочисельні проекти в рамках громадського бюджету. Опитування розкрило недостатній рівеньзабезпеченості мешканців місцями прикладання праці, об'єктами соціальної інфраструктури, незадовільний стан вуличної інфраструктури та забезпечення потреб у громадському транспорті, так само, як і низький рівень інклюзивності міського середовища, що, разом з відсутністю бізнесової функції у районі, зрештою, не дає можливості жК «ЛікоГрад» стати багатофункціональним міським простором згідно інтегрованих підходів конструювання інклюзивного простору. Підсумовуючи зазначене, можна зробити висновок, що шлях українських міст до партисипативної демократії тільки зароджується, він потребує глибокого усвідомлення представниками місцевих громад свого значення і відповідальності за прийняття управлінських рішень в інтересах всіх мешканців.

Ключові слова: неоліберальні міські практики, інтегрований міський розвиток, участь громадськості, Київ.

\section{Introduction}

Chaotic construction, increased demands on transport and the social infrastructure, the lack of green spaces, and the depreciation of public spacesproviding social interaction as well as homogenization and unification of landscapes and other negative modern transformations of urban areasare taking place in Ukrainian cities. These features are found especially in cities with a million-plus population and are mostly the results of the domestication of certain neoliberal practices in the field of urban planning and management in the post-Soviet space (Golubchikov 2016). Urban planning is increasingly seen as a means of maximizing profits for the sake of meeting the needs of local real estate elites. Itis becoming a major tool for economic development and capital accumulation of specific social groups. At the same time, local communities are usually excluded from the new urban coalitions, which see the city not as a place for comfortable living for locals, but as a source of added economicvalue "built" into the world economy (AlHamarneh et al., 2019). Neoliberal approaches not only subordinate the system of city management to the capital, but also alienate it from its history and its inhabitants.

In search of a way out of the pitfalls of neoliberal approaches in the system of urban planning and governance, EU cities widely use integrated urban development practices, which include active public involvement in decision-making processes at all levels and at all stages (especially early) of urban development. Integrated urban development can be defined as a decision-making system that considers opinions of all segments of society and ensures an understanding of the consequences of decision-making in every particular area in relation to all other areas (Bondar, 2018). Integrated urban development is a necessary precondition for confronting many challenges faced by cities today and it makes them more balanced and comfortable for local people.

The capital of Ukraine, Kyiv, is increasingly becoming an arena for neoliberal urban processes (Dronova \& Maruniak, 2019). At the same time the city has been implementing certain solutions and initiatives to implement standards of integrated urban development for a long time, all within the framework of international technical assistance and experience exchange programs. One such initiative, for example, is the "Concept of Integrated Development of Podil District of Kyiv" Project, (National Policy... 2018; Development Concept... 2019). It should be noted that the experience of technical assistance projects implementation in Ukraine shows that, as a rule, such initiatives are phased in after the termination of international funding. Besides, the areas which are not involved in projects, rarely receive an implication of positive international experience at all. The purpose of this study is to investigate the state of integration of certain districts of Kyiv which are not involved in international projects. One specific example of a new residential housing is Liko-Grad. Results of a survey of residents conducted by the authors in 2018 and 2020 raise questions regarding the satisfaction of local community members about the level of amenities and comfort of their place of residence, inclusiveness of the urban environment, involvement in decision-making, as well as awareness and willingness to participate in development of their residential housing.

Theoretical and methodological background of the research

Neoliberalism is widely recognized as the dominant ideology that currently extends into post-socialism development (Stenning et al., 2010). Golubchikov and his co-authors comment on post-socialist urban development using the concept of hybrid spaces arising from the fusion of neoliberalism and socialist heritage.They point out that the socialist legacy has been alienated from its history and become a infrastructure for neoliberalization (Golubchikov et al., 2014). Urban landscapes, which were formed under socialism, are adapting to new conditions and influenced by the political, economic and cultural transition to capitalism (Sykora, 2009). Due to morphology, land use and social segregation in postSoviet cities, some typical capitalist urban districts can be found next to the urban landscapes resembling frozen mirrors of socialism (Sýkora \& Bouzarovski, 2012).

It is important to link neoliberalism processes to the regulatory environment in which it exists. The existing neoliberalism (Peck et al., 2009) exploits and produces socio-spatial differences while neoliberal reform initiatives are imposed in the context of specific institutional landscapes and historical political environments (Robinson \& Parnell, 2011). And if this environment does not include historical heritage of community building approaches and the use of certain 
participatory practices and the experience of public participation in decision-making, neoliberalism becomes distorted and hypertrophied under the influence of socalled "zombie socialism" (Chelcea \& Druţă, 2016). Some specific studies show that the practice of integrated urban development is more common in EU cities than in post-socialist countries (Brankica, 2018).

Centralized methods of planned economy in urban planning were used in Ukrainian cities in Soviet times; they did not involve the public in decisionmaking. Cities were developed using a top-down approach and people's genetic memory of public participation was not formed. This history affects the modern processes of implementing democratic approaches in the urban management system, which usually must support the active interest of citizens in urban development processes. A number of laws of Ukraine since independence define mechanisms for ensuring transparency and a consideration of public opinion today. In particular, the Law "On Local SelfGovernment in Ukraine" guarantees the right of the territorial community members to influence local decision-making in the form of local referendums, general meetings, public hearings, the introduction of a local initiative for consideration by a local self-government body, and initiation community associations (Law of Ukraine... 1997). However, the path of Ukrainian cities to participative democracy is just emerging, it requires a deep awareness of local communities abouttheir importance and responsibility for management decisions in the interests of all residents. In the vast majority of cities, the implementation of public initiative is limited to nontransparent information and limits on publicopinion. Also there is often a practice of inserting falsehoods in public hearings on urban development (Maiko, 2017; Matveeva, 2017; Levchenko, 2020).

In fact, public participation and community involvement are an inseparable part of a democratic society development in the contemporary world. They are concerned with various mechanisms of public opinion consideration and allows the community to influence public decisions (Levchenko et al.; 2018). Today there is a rapid decentralization reform in Ukraine which is difficult to put into action without understanding the mechanisms for implementation and an effective involvement of citizens in decision-making. The overall objective of public involvementin urban areas is to establish trust-based relations between territorial communities and local authorities, thus increasing mutual responsibility and a new interaction experience. Examples of individual EU cities demonstrate that strengthening the role of citizens in meeting the needs of the community and streamlining the living environment is an important element in the development of local self-government (Bovronet al., 2008). Public activism is also one of the key tools for counteracting the non-transparent decision-making in the process of neoliberal urban planning,when urban space is left at the mercy of project developers.
The concepts of integrated urban development also focus on the same goal. They can be considered as an informal and flexible planning tool that focuses primarily on the needs of citizens, rather than on someone's individual economic interests. Integrated planning approaches are based on a reinterpretation of rational planning of the 1950s (Abukhater, 2009; Lawrence, 2002). Such new approaches are the result of correlation between urban context and the overall development of socio-economic relations which have become extremely dynamic in recent decades (Pickett et al., 2004; Ray, 2012). Various aspects of urban life (environmental, economic, social and cultural) are intertwined and they are influenced by the interests of various factors and groups. The complexity and interconnection of urban spaces, values and socio-economic conditions tend to continuously evolve in space and time. Success in urban development can only be achieved through a flexible complex approach that shapes the nature of integrated planning. Events that relate to the physical renewal of the city should be combined with those that promote social integration, economic development, promotion of the city's image and environmental protection, all which are consistent with the concept of sustainable development (Integrated Urban Governance, 2011). In addition to a strong institutional framework and a revision of the regulatory framework, this approach requires the establishment of strong partnerships between local citizens, businesses and different levels of government as well as the appropriate decision-making body at the local level. For sure, a community is the place where democracy "lives", a new participatory culture grows, and tactical urbanism approaches can be applied (Lydon \& Garcia, 2012). Tactical urbanism approaches are tools related to the quality improvement of urban environment and life of citizens through small-scale, short-term, lowbudget events, all which bring about long-term changes and attract investments. Such activities instantly improve some aspect of a community life and demonstrate to city leaders that there are opportunities for simple and successful changes. The main goal of such approaches is to change the way people see their city and seek ways to make it better (Wekel, 2016). Thus, the integration begins locally. The creation of quality neighborhoods is a critical prerequisite for the construction of an inclusive and comfortable city life for all residents. In order public projects to be successful, they should be proposed primarily at the level of urban neighborhoods.

But the question remains whether or not the residents of cities in Ukraine are content with the state of their comfort and inclusiveness and about the planning of new residential developments? Are these residents ready to take part in such events? We investigate this issue at the level of one residential housing development Liko-Grad.

\section{Research methodology and data}

The article summarizes the study of public participation processes in decision-making regarding the Liko-Grad residential housing development in Kyiv, in particular the focus is on the organization of integrated and inclusive urban space. The research, which was conducted during 2018-2020, consists of four stages. 
Field research, conducted in October 2018, was the first stage. It included observations, taking photographs, making sketches as well as administering a survey of residents. The survey instrument was designed based on previous studies of integrated urban development and public participative practices in other cities.

In order to determine the perception and level of public involvement in addressing the development of the neighborhood, the 2018 survey included the following blocks of questions: whether the residents are satisfied with the state of beautification of the district; whether they like their places of recreation and entertainments; whether they participate in solving the problems of the district; and information about how decisions are made. At the same time, the aim of the survey was not only to identify the level of awareness and perception of residents related to the quality of life in the area, but also to encourage them to think about the importance of everyone's participation in the development of their housing.

The survey included 44 completed responses. Quantitative results which formed the basis for analysis and discussion were the following: $52 \%$ of the respondents were women and $48 \%$ were men. Respondents represented different age groups (up to 25 years $-25 \%$ of respondents, from 25 to $35-30 \%$, from 35 to $45-27 \%$, from 45 to $60-16 \%$ and over 60 years $2 \%$ ). $48 \%$ of respondents have lived in Kyiv for all their lives, $18 \%$ - over 20 years, $16 \%$ - $20-10$ years and $18 \%$ have lived in the city for less than 10 years. Education: $77 \%$ of respondents have higher education, $23 \%$ incomplete higher education. Sector of employment: public authorities and local governments - $2 \%$, finance and insurance - $14 \%$, education, science, culture, health $34 \%$, industry, construction, transport, communications - $7 \%$, trade and services - $16 \%$, publishing - $2 \%$, private entrepreneur - $7 \%$, student - $7 \%$, pensioner - $4 \%$, temporarily unemployed (maternity leave) - 7\%. In terms of income per capita, the largest share of respondents are middle-class: 5-10 thousand UAH - 36\%, 10-20 thousand UAH - $39 \%$, less (up to 5 thousand UAH) $16 \%$ of respondents and $9 \%$ of respondents receive more than 20 thousand UAH.

The second stage included an analysis of results, screening of open scientific and statistical information, further processing of the surveys for analysis, as well as decisions on what data to analyze further. Decisions were made to analyze the inclusiveness of urban spaces, as well as the district's transport system, the state of the infrastructure, the public transport routes developedin cooperation with the Kyiv Municipal Company "Road Traffic Management Center" (RTMC). All the investigations were concentrated on the integrated urban development.

In May 2020, in order to investigate the district residents' mood changes over time as well as study the inclusiveness of urban space for all segments of the population, the authors conducted an online survey of Liko-Grad residents (stage 3) on the Facebook platform with the members of the community due to COVID19 restrictions. The advantage of this survey was that it provided a significant number of responses from the most socially active population. The authors had the opportunity to interview not only representatives of different segments and groups of the population, but especially those interested in the development of their neighborhood.

The 2020 questionnaire included the following blocks of questions: are the residents satisfied with the elements of the social infrastructure of the district (retail businesses, schools, kindergartens, health care facilities, areas for walking pets and parking lots); are the residents satisfied with the elements of street infrastructure and public transport; are the elements of public spaces arranged satisfactorily for use (squares, parks, playgrounds, sports grounds, sacred buildings); do they participate in solving the problems of the district; and, in general, are they interested in participating in the decision making and is there information on decision making processes in the area? The rating scale included the following answer categories: 1 - very poor; 2 - poor; 3 - normal; 4 - good; 5 - excellent.

Thus, 357 respondents were interviewed in 2020, including: $78 \%$ women and $22 \%$ men. Age categories: residents aged 20 to $40-68 \%$, 40 to $60-30 \%$, older than $60-2 \% .29 \%$ out of surveyed residents have children under the age of 3 , and $3.5 \%$ have a disability, which is important in analyzing the state of inclusiveness of the urban space in the district.

The $4^{\text {th }}$ and final stage of the study included the following: processing the survey results in combination with analysis of open-source data on the public budget of Kyiv, updating analytical, statistical, design and scientific information, and the processing all findings using socio-geographical methods, in particular analysis, synthesis, generalization and mapping.

\section{Results and discussion}

Description of the residential housing Liko-Grad. The residential study area, Liko-Grad, is located in the Holosiivskyi district of Kyiv between Williamsa, Lomonosova and Marshala Koneva streets. Also, part of its territory is next to the closed military base of the Security Service of Ukraine. The Liko-Grad residential complex is 34.4 hectares with a population of approximately 21,000 residents. Construction of the complex began in 2006 with the first residents moving in 2008 .

It is important to understand the context of the housing development in which it is located. Based on open data, observations and personal perception, the authors developed a GIS map of the neighborhood and its surroundings, which is closely related to the research site (Fig. 1).

It is worth pointing out the territories of the Taras Shevchenko National University of Kyiv (designated as KNU on Figure 1), which occupies $28 \%$ of the neighboring territories, a typical Soviet building, which is less represented near the metro station Vasylkivska and mostly in the Teremky-2 neighborhood. Residential housing includes Evrika, Venetsia, Soniachna Brama, Chotyry Sezony and small club houses on Williamsa Street which have a concept and planning design similar to the Liko-Grad residential housing and are an important component 


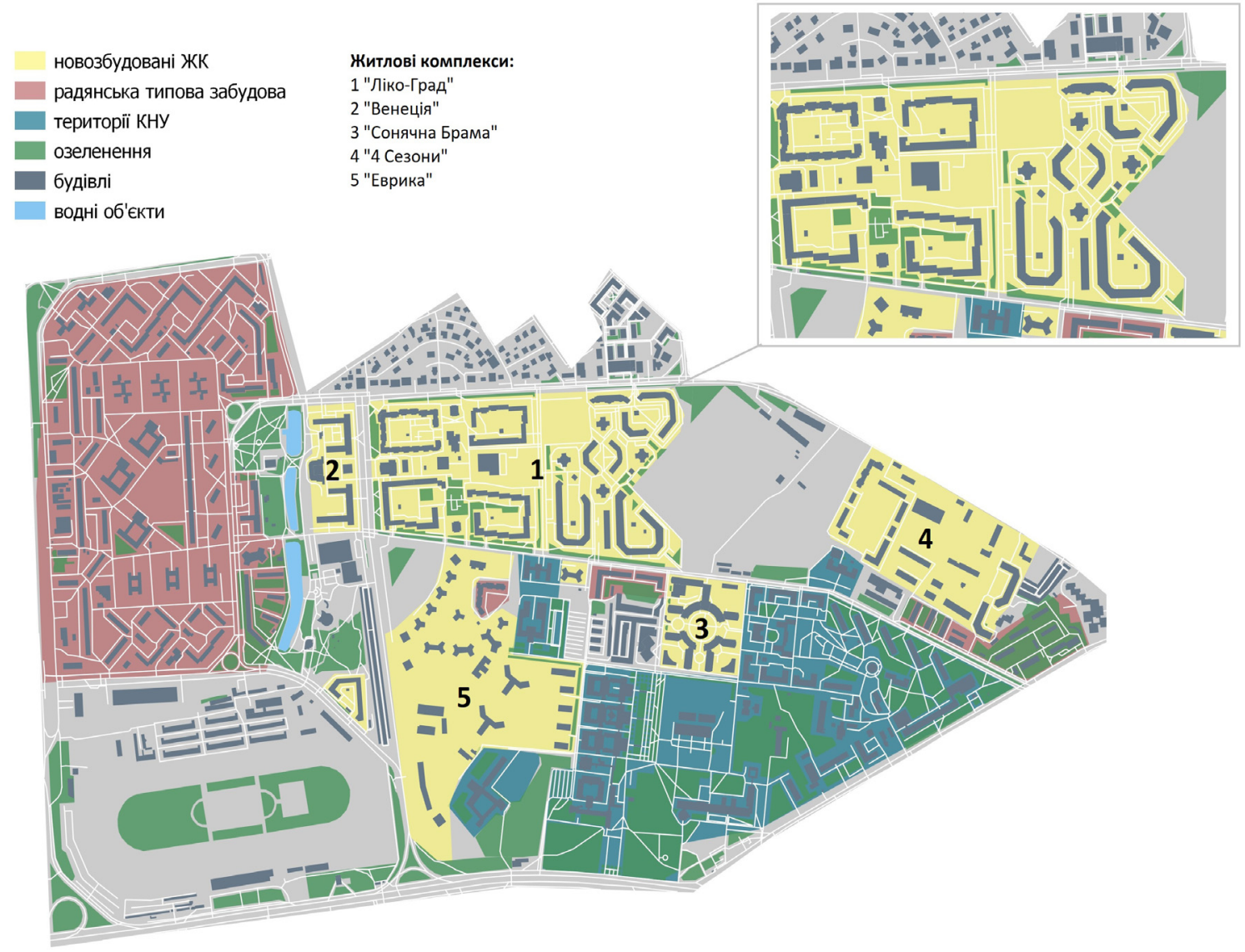

Fig. 1. The context of the location of the "Liko-Grad" residential development (prepared by authors)
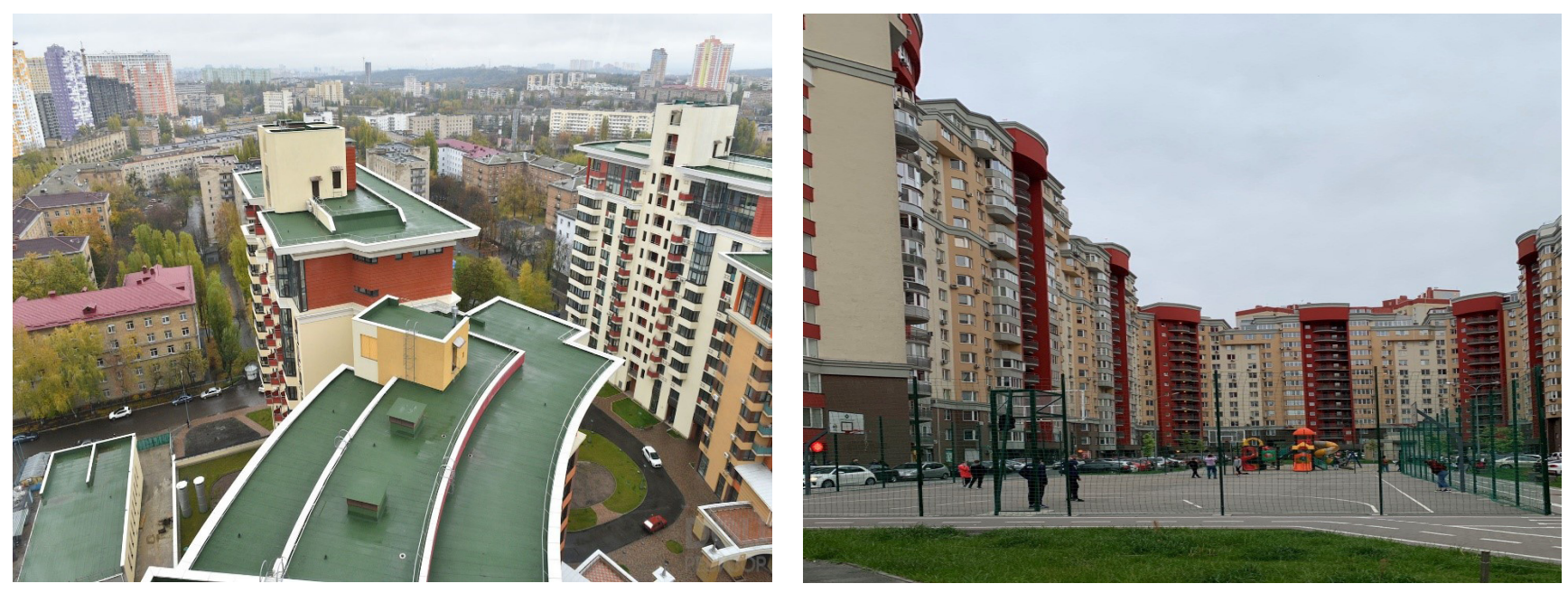

Fig. 2. Landscapes of new buildings Sonyachna Brama and Liko-Grad (photos by authors)

of its surrounding. It is worth noting that the construction of new housing is on a quiet democratic university district where only Soviet typical houses previously were located and which led to a certain social polarization and segmentation of the society. Higher-income residents quickly occupied the apartments in the new residential housing. At the same time, the opening of new subway stations in 20112013 led to the price increase for the real estate and basic commercial services in this district. Now one can observe a significant gap between the standard of living and income of residents of Teremky-2 and nearby newly built residential housings (Fig. 2).

The Liko-Grad residential housing itself (the height of residential buildings averages 14-16 floors) was completely designed and built by the LikoHolding development company in several stages. The neighboring residential housing Venetsia and residential housing Liko-Grad Perfect Town, which is currently under construction, were also built by Liko-Holding. Public opinion was not considered, not only in the process of planning of the prospective 


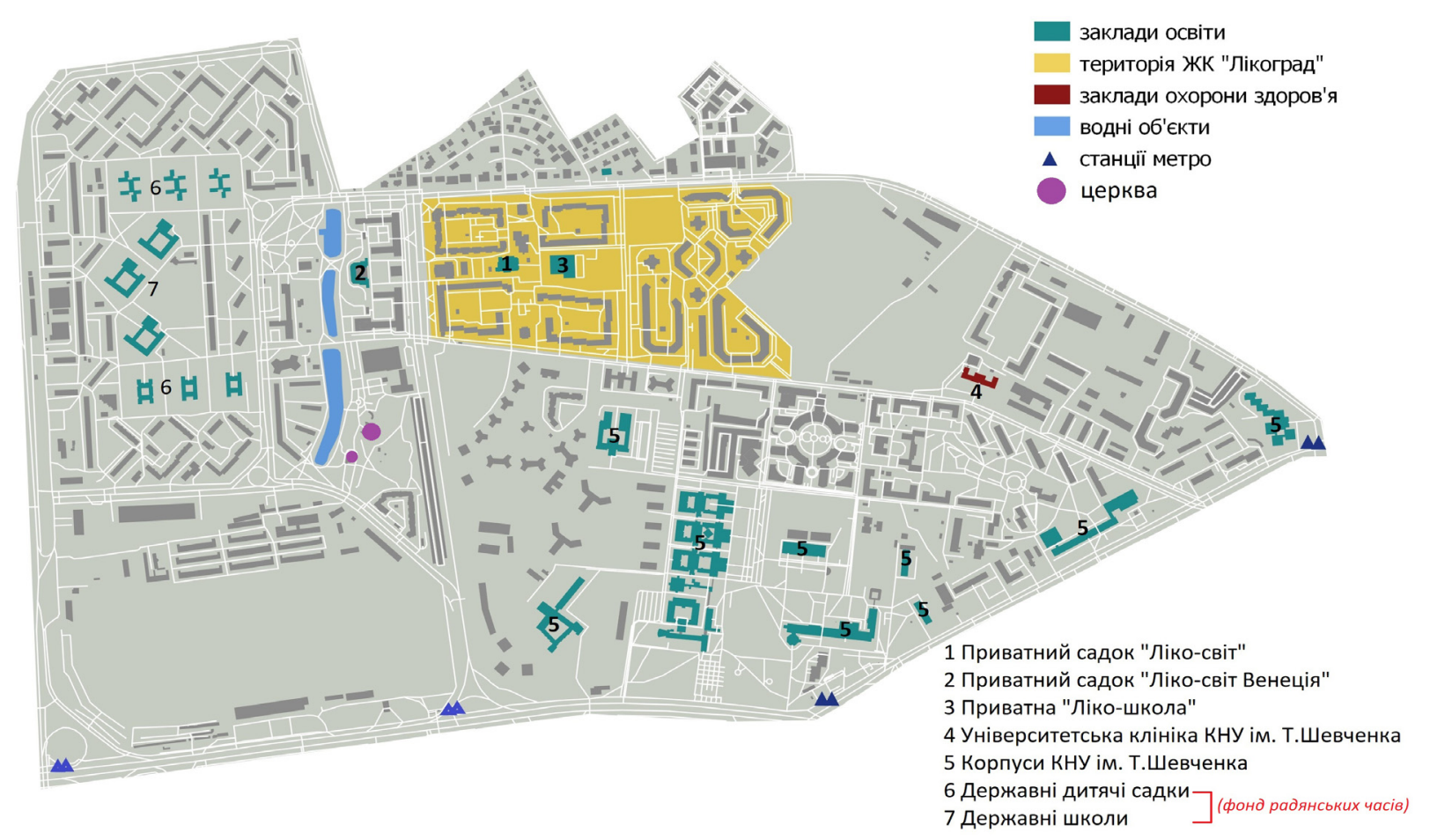

Fig. 3. Social infrastructure in the area of Liko-Grad residential housing (prepared by authors)

housing complex, but also in efforts to further improve the surrounding areas. Thus, decisions on the number of floors in a building, landscaping, the number and materials used in constructing playgrounds and sports grounds as well as the parking areas were made exclusively by the developer who was guided primarily by economic interests which is characteristic of neoliberal approaches to urban decision-making (Logan and Molotch, 1987). The price of rent and purchasing cost of the area in square meters were the most important factors in planning the residential complex.

The need for infrastructure desired for a comfortable life of newcomers was also not considered during the construction of the housing development. At the time of construction of Liko-Grad, the nearest available preschools and secondary schools were located only in the residential area Teremky-2 (Fig. 3). Over time, a private kindergarten and a private school were built on the territory of the housing. Another kindergarten is under construction at the moment. It should be noted that next to the residential area there is also a physic and mathematical lyceum and buildings of Taras Shevchenko National University of Kyiv, which is an advantage for both the education and employment of local residents.

Beautification, landscaping and infrastructure. At the time of the two surveys, the level of satisfaction with beautification, landscaping and social infrastructure was extremely heterogeneous. In general, $69 \%$ of respondents were very satisfied with the beautification of the district,
$41 \%$ of respondents were satisfied with the availability and condition of green and public spaces, almost $49 \%$ of respondents feel safe there and consider them open to all groups and only $4 \%$ were unsatisfied with the places of rest and entertainment in the neighborhood.

However, if playgrounds or grocery stores (supermarkets and mini-markets) was assessed mostly positively by residents, the majority of respondents assessed the availability of employment places, social infrastructure facilities and pedestrian accessibility of kindergartens or schools negatively (Fig. 4).

Moreover, according to LUN Misto open platform, queues for kindergartens in Liko-Grad average between 665 to 1225 children per vacant place (Dovzhyna cherh... access on November 17, 2020). Such a long queues indicates that there are much more children in the district than there are places in the existing kindergartens. Most parents will have to place their kids in kindergartens in other neighborhoods, most likely outside of pedestrian accessibility. Such situation is typical for major quantity of new neighborhoods of Kyiv.

Another problem was the lack of public transport on some streets, which indicates the inconsistency of dense development projects with the nearby transport system. In cooperation with ME "Center of Traffic Management" in Kyiv, the following specific problems were identified regarding the transport system of the district: the need of traffic light regulation and streamlining on Meytusa Street, which has not been transferred to the city's balance sheet because of a 
number of problems; the problem with traffic density on Lomonosova Street which is overloaded, pedestrian crossings and sidewalks need to be better arranged; organization of the entrance to the Liko-School which is currently inconvenient and dangerous; and the dangerous intersection of Koneva and Kasiyana streets. There is also no public transport on some streets, in particular Koneva street. It is important to arrange the transport route on Kostycheva Street as in the end of the pedestrian zone and near the lakes there is a disorganized parking space, and people walk between cars which is dangerous.

Due to the large number of private car owners, there is a large-scale problem with parking. First of all, there is a need to solve and provide modern underground parking, because the city should not be for cars but for people. The construction of bicycle lanes for commuting to the metro station as well as bicycle cages for safe storage of bicycles will help to improve the transport situation in the neighborhood.
Detailed problem analysis and recommendations for the transport system improvement are schematically presented in Figure 5.

Inclusiveness of urban space. Within the context of studying features of integrated urban development, there were questions asked about those with disabilities. The results show that $62 \%$ are satisfied with the presence of surface level pedestrian crossings. However, 54\% are dissatisfied with the lack of traffic lights at the crossings. $70 \%$ of respondents with disabilities noted the lack of sound signals at the crossings, $85 \%$ are dissatisfied with the lack of Brailletransliteration, plates and signatures. $77 \%$ of respondents noted the lack of easy grades, slopes, ramps, which limits their ability to move and $70 \%$ are dissatisfied with the state of improved public transport.

The results of the survey of parents with children under 3 years old show that $61 \%$ are upset because of the lack of kindergartens in the neighborhood, 63\% are dissatisfied with the quality of kindergartens (price in private kindergartens, conditions and level of service, and

\section{Availability and pedestrian accessibility of kindergartens (10-15 min.) 357 answers}

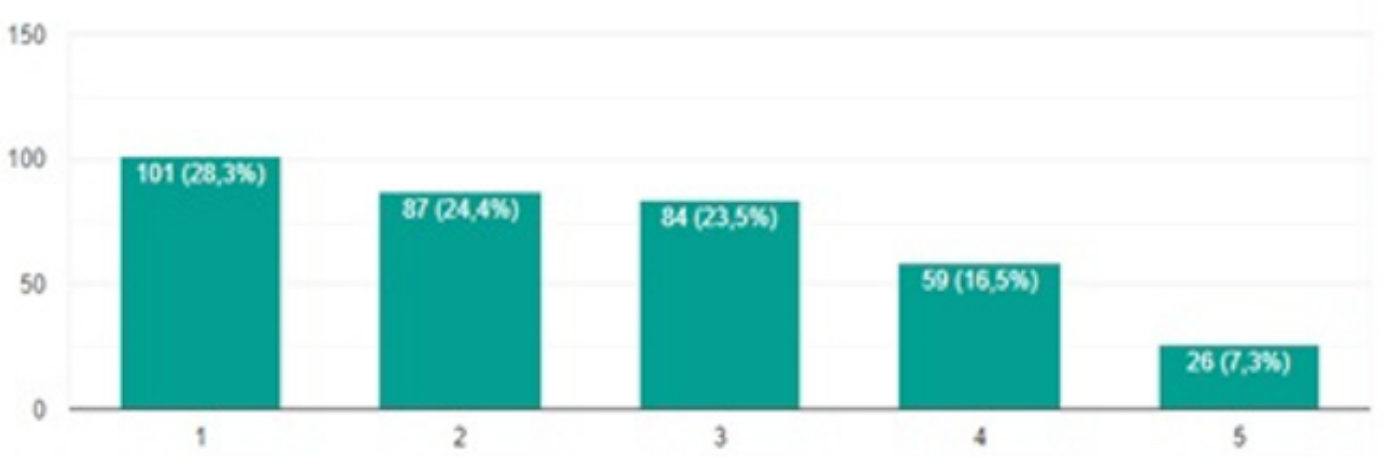

\section{Availability and pedestrian accessibility of secondary schools (10-15 min.) 357 answers}

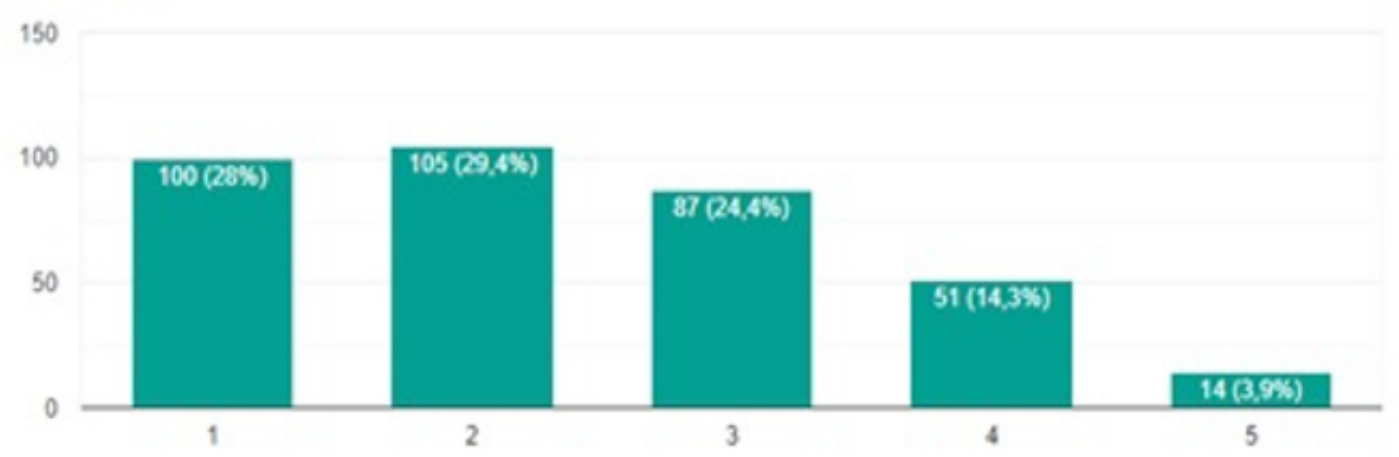

Fig. 4. The Liko-Grad Residents' assessment of pedestrian accessibility of educational institutions (1-very poor, 5 - excellent, according to 2020 survey) 

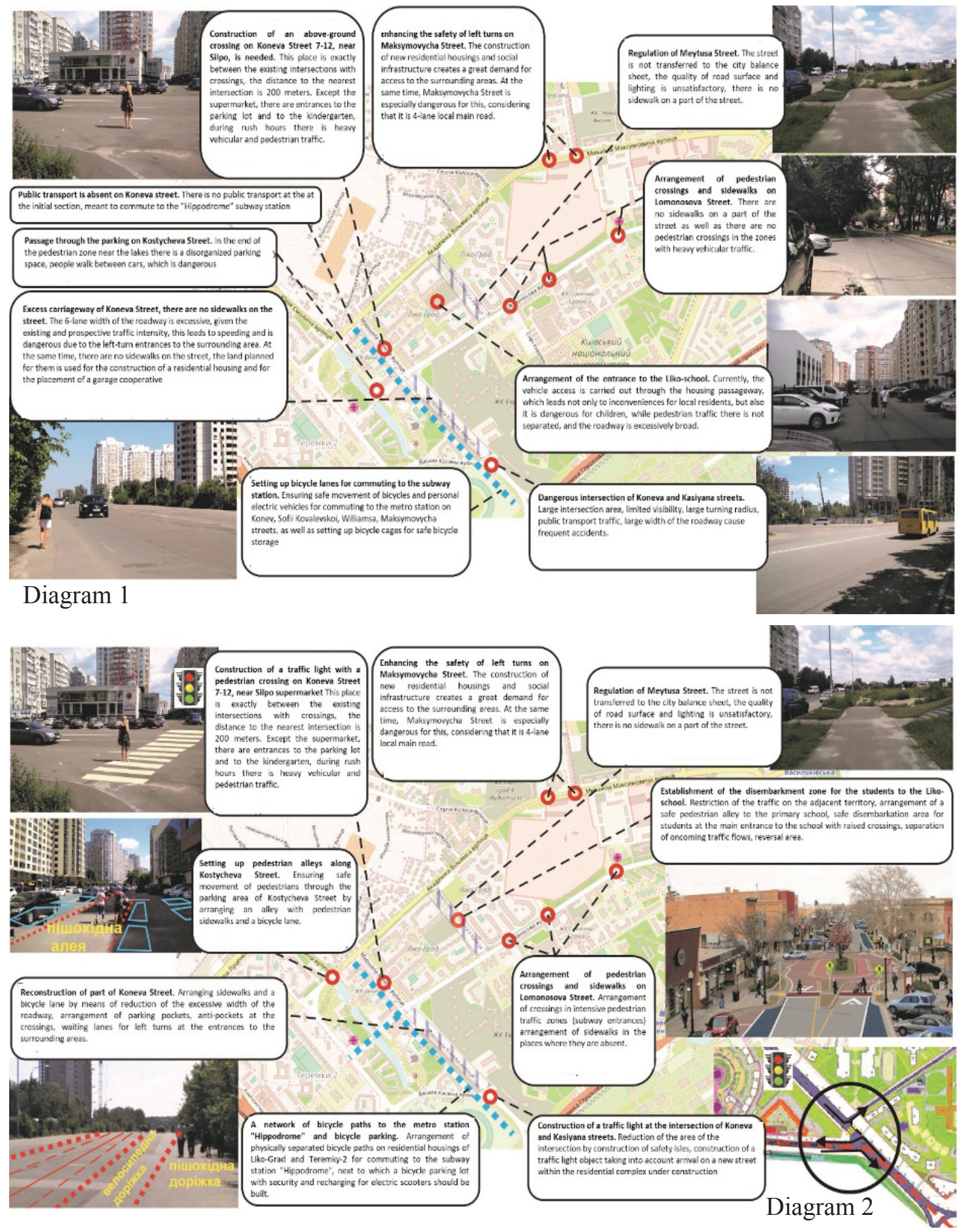

Fig. 5. Transport issues of Liko-Grad district: Diagram 1 - problems, diagram 2 - possible solutions, 2018. (based on the experience of ME "Center of Traffic Management")

the remoteness of public kindergartens). On the positive side, $54 \%$ of parents are satisfied with the health facilities that are within walking distance and $61 \%$ are satisfied with the beautification of the playgrounds.

Based on the above, it can be concluded that the organization of inclusive urban space remains an open question in the Liko-Grad residential area because this issue was assessed negatively by residents and which is confirmed by the authors' assessments. In particular, the vast majority of all respondents are not satisfied with the lack of bike lanes (90\%). Also, most respondents noted the absence of sound signals at the crossings and transliteration in Braille, signatures and signs, sloping ramps and poor street lighting in the dark (Fig. 6). These results identify significant challenges and prospects for the development of inclusiveness of Liko-Grad space in the presence of desired and relevant community requests. 
Presence of sound signals at the crossings

a) 357 answers

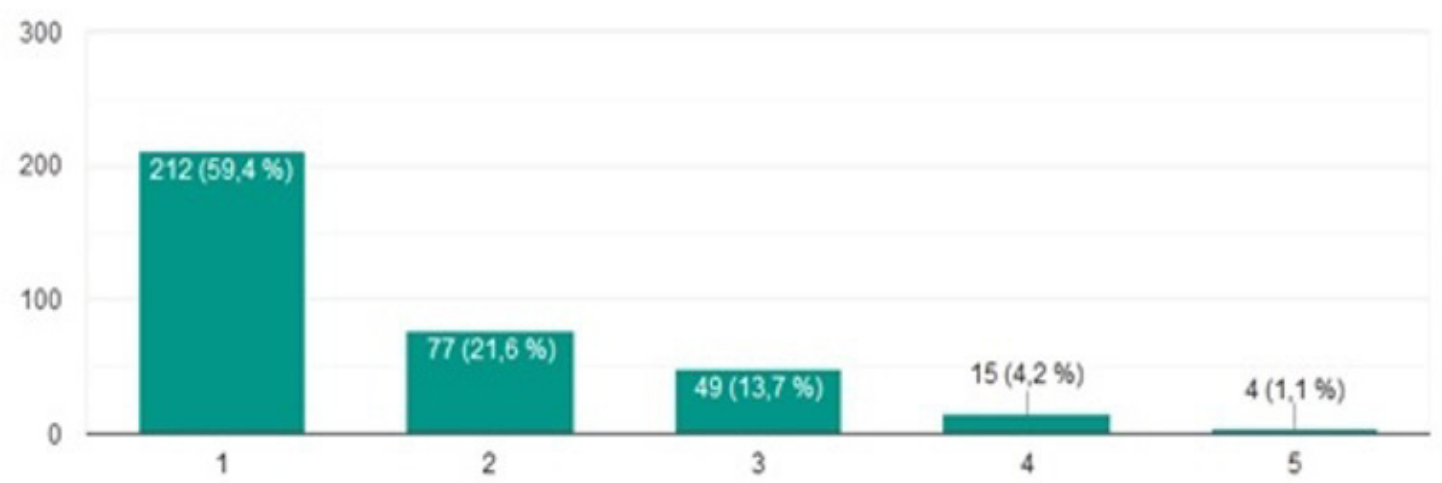

Presence of Braille transliteration, signatures and plates

b)

357 answers

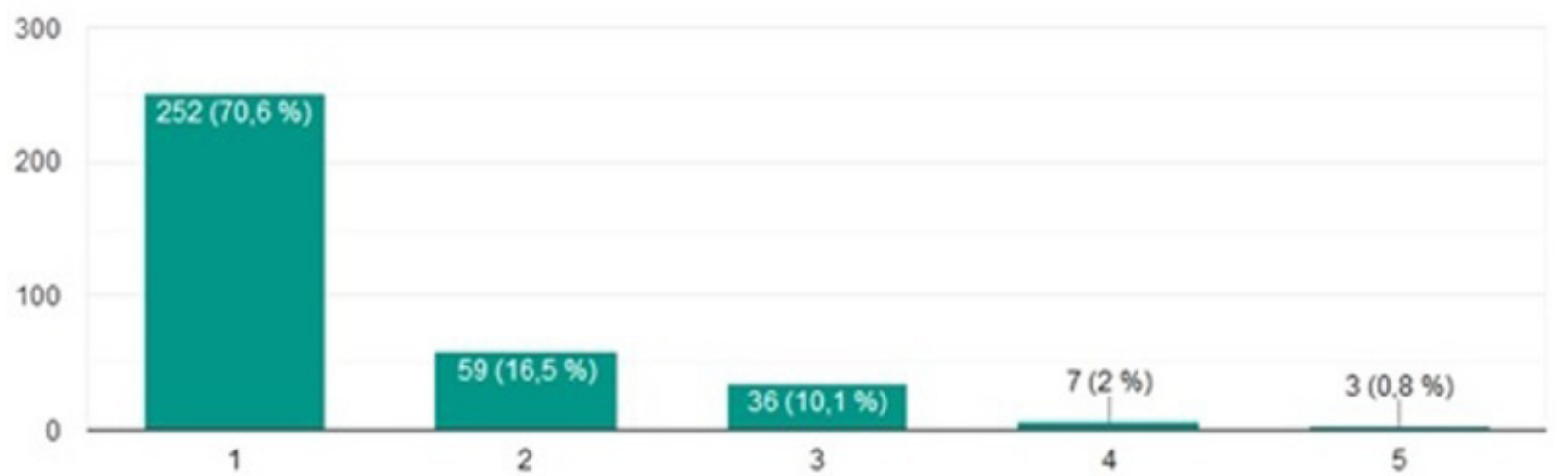

Presence of sloping ramps and slopes on sidewalks, ramps (<8\%)

c) 357 answers

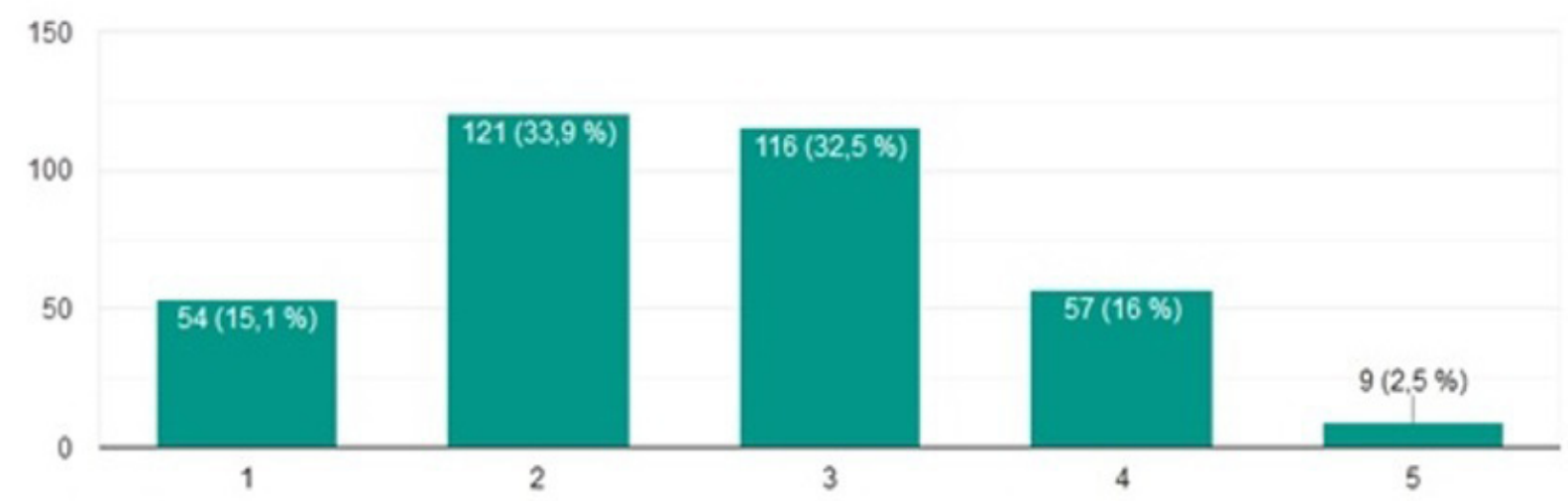

Fig. 6. a) Respondents' answers to the presence of sound signals at crossings; b) the presence of Braille transliteration, signatures and plates; and c) and the presence of sloping ramps and slopes on sidewalks, ramps. (Based on 2020 survey) 
There is a significant number of commercial establishments in the territory of the housing: cafes, shops, medical centers and pharmacies. Residential housing is dominant and the lack of more business functions, as well as places of employment, eventually do not allow LikoGrad to become a multifunctional urban space according to integrated approaches to urban development or "the third place" after Oldenburg (1999). However, it should be noted that the proximity to the Taras Shevchenko National University of Kyiv is a potential source of creation of the innovative function of this location.

Summarizing all the above, we can outline the threats to the integrated development of the neighborhood; these include housing density, insufficient employment opportunities, low availability of accessible schools, kindergartens and other institutions, insufficient green and public spaces, low level of public transport and poor infrastructure (especially the dominance of parking lots and lack of bike paths) and low levels of inclusivity.

Public participation in decision making. When Liko-Grad was completely inhabited, the formation of a community began there, which, as of today, can be equated to levels of non-participation and symbolic events under Sherry Arnstein (1969), or to passive participation and providing information participation according to UNDP approaches (UNDP 2002). Of course, meeting new neighbors and the emergence of common practices, as a rule, cannot happen simultaneously with the purchase of apartments. However, it should be noted that community selfrealization exists today, but its development occurs at a slow pace. We analyzed the activity of residents within the context of social networks (Fig. 8). In particular, only $41.9 \%$ of the population are not involved in the online communities in their residential housing while $53.3 \%$ of residents are connected via social networks and $4.8 \%$ are members of the NGO "Community of Liko-Grad" (Fig. 7).

Despite significant activity in social networks, participatory practices regarding the organization of urban space are rarely transferred intoreal-life. The authors analyzed the projects submitted by the Liko-Grad residents within the framework of the public budget of Kyiv for the last two years. Three projects were submitted in total, two of which were concerned with improving playgrounds and were implemented. The third aimed at

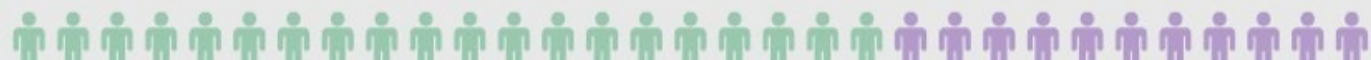

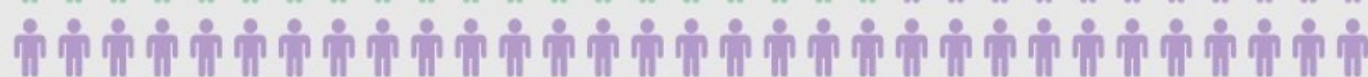

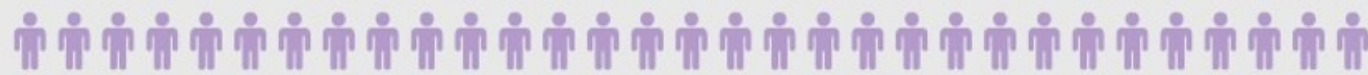

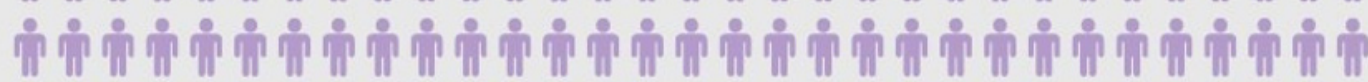

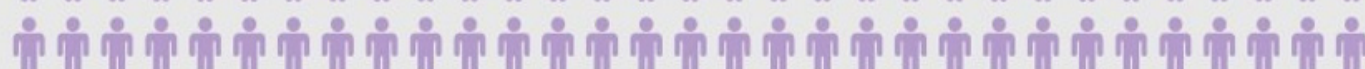

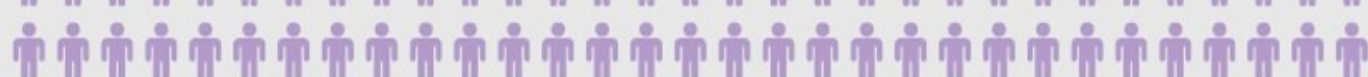

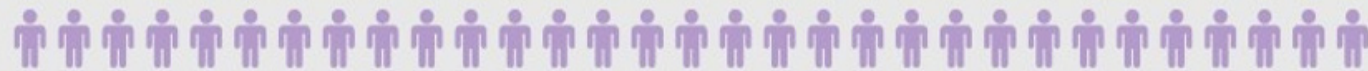

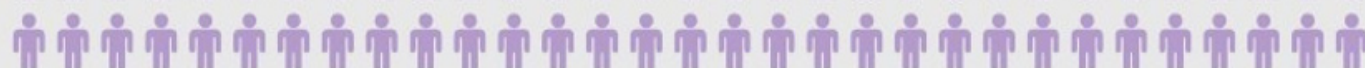

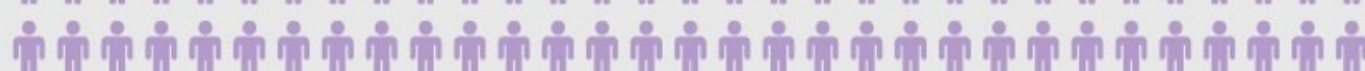

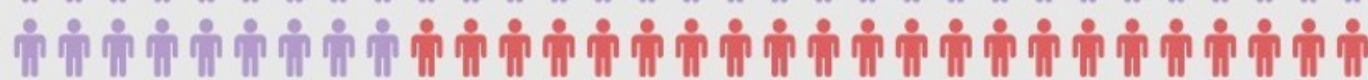

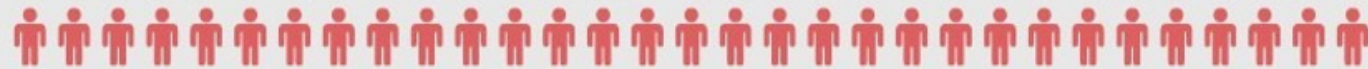

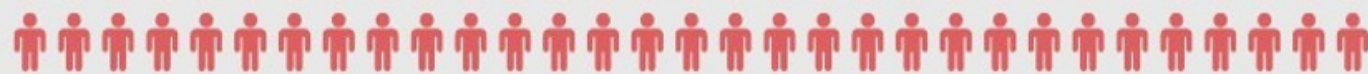

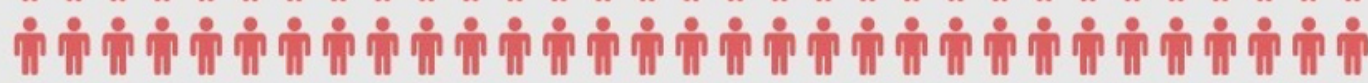

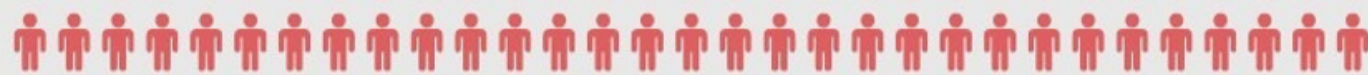

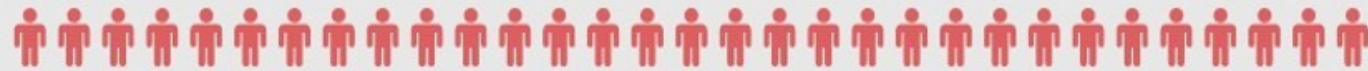

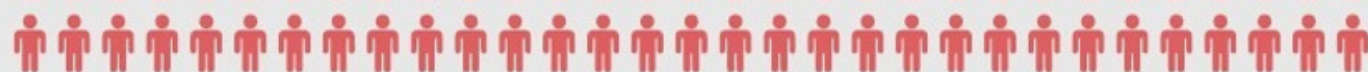

members of NGO "Community of Liko-Grad"

residents, involved in Facebook groups

not involved in social media

Fig. 7. Involvement of Liko-Grad residents into social networks (developed by authors) 
landscaping the area in front of the residential complex and was rejected because that area is privately owned.

According to the results of the 2018 survey, only 12\% of respondents are interested in decisions making in the district and only $39 \%$ are willing to participate in solving the problems. Probably, the main reason for such answers is that some residents are not yet sufficiently aware of their responsibility for the development of the city. Respondents in 2020 also did not show a high awareness of their "right to the city" nor a clear understanding of the processes taking place in the community and how they are addressed.

Perhaps this attitude is still attributed to the stereotypes of the Soviet system of urban management when all decisions were made using a top-down approach, and people got used to the fact that "someone" makes all decisions for them. Such genetic experience was formed according to criteria which are beyond the understanding of the importance of public participation. It prevents the identification of real, informal, public initiative and creates artificial barriers to the formation of local civil society institutions.

To some extent, the current situation is influenced by the low level of citizen awareness and their lack of experience in solving problems of the district or city as a whole. On the positive side, according to the analysis of responses in 2018, 34\% of respondents have experience in solving problems of the city and district, and $44 \%$ have suggestions for solving specific problems. The analysis of 2020 showed that about $66 \%$ of respondents remain interested in decision-making in the area, which may be the evidence of higher activity of residents involved in relevant social networks. Only about $13 \%$ are actively involved in decision-making and in activities related to the development of the neighborhood (Fig. 8).

Additional insights into the social networks shows that an important component of participatory practices is the so-called "neighborhood cleanup" which began in March 2020 and is held on a regular basis. The effort is to clean the areas around the residential housing (which are not part of the house communal service area, but provide an unpleasant view from the windows), as well as

\section{I am interested in the decision-making process}
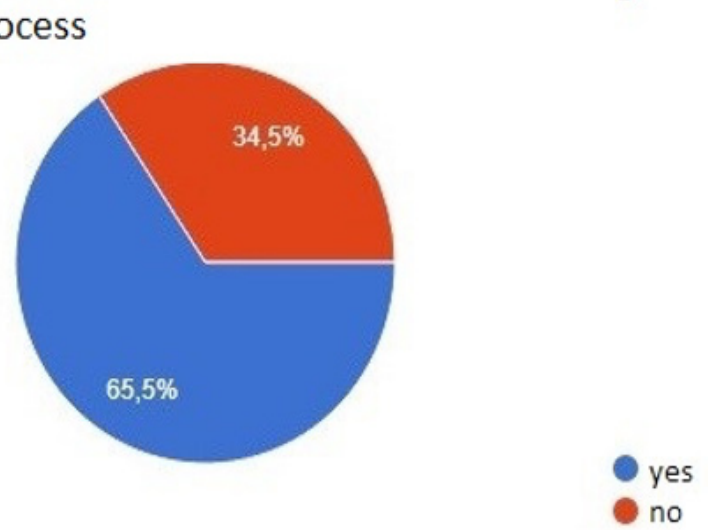

planting flower beds in the yards. Figure 1 clearly shows that the territory of Liko-Grad is really not sufficiently landscaped and residents are still trying to fulfill the need with natural landscape settings. Such participatory practices are evidence that the community is gradually moving from the stage of formation to more dynamic actions. They also identify significant prospects for further cohesion within the community and its integration into the larger surrounding space.

In order to understand the strengths and weaknesses, as well as further opportunities and threats to the LikoGrad community, we conducted a SWOT-analysis of the prospects of providing residents with integrated development of the neighborhood (Fig. 9).

In general, the research results show that at the moment the community of Liko-Grad is just beginning its formation, although the residents have been living together for a considerable period of time. The emergence of the first participatory practices can be observed today: neighborhood cleanups, landscaping projects, active discussions on social networks. This is a channel that stimulates the emergence of a local democracy in LikoGrad. Nevertheless, there are weaknesses that, with the right approach, can also be turned into a positive or growth zone:

- Lack of a cohesive community can be strengthened through frequent good neighborly practices and an involvement in project discussions.

- Community activity which is active only when it is triggered by circumstances can be further transformed into systematic participatory practices. - The impossibility of influencing basic living conditions makes it possible to direct activity to improve environmental conditions and landscaping.

Moreover, the existing cases of participatory practices should be a good example for the Liko-Grad community. The implementation of public budget projects can be a source of inspiration for new projects in the coming years. There are also opportunities to attract foreign investment and international cooperation within the framework of integrated development projects of the neighborhood. The "Concept of

\section{I am actively involved in decision-making and all activities related to the development of the neighborhood}

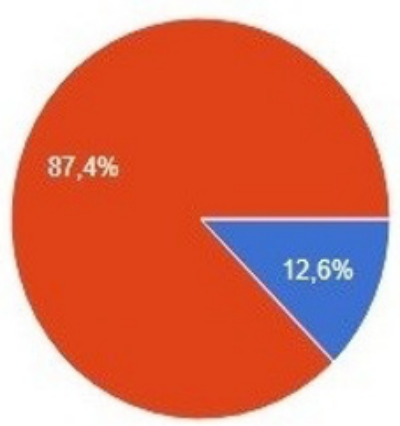


Integrated Development of Podil District of Kyiv" is an such example.

Of course, there are external threats to community participation, particularly official restrictions due to the COVID-19 pandemic. Residents are more focused on solving internal family problems during the crisis, and communication within the community becomes almost impossible under the lockdown. At the same time, the background of the Liko-Grad community, laid in previous years, creates significant opportunities and prospects for its further development, provided that residents are sufficiently involved along with the assistance of business and municipal agencies.

\section{Conclusion}

In the process of applying centralized, rational and subordinate approaches in urban planning of Soviet times, the Ukrainian cityresidents did not have the opportunity to gain experience in applying certain public participative practices in urban decisionmaking, which would be fixed at a genetic level. With independence, the cities of Ukraine were given the opportunity to review urban planning approaches and introduce community-oriented development of the city. However, this possibility was not considered in time and most cities of Ukraine began to develop with the use of neoliberal urban practices which often take on distorted and hypertrophied forms. The same applies to the development of Kyiv where individual districts are not developed in accordance with the general vision of the city and a specific urban space is often viewed as a commodity that needs to be sold at the highest possible price in order to maximize short-term profit. The official discussions on the use and development of urban space in Kyiv are not transparent and are resolved in favor of the economic interests of specific privatebusiness coalitions with minimal involvement of local communities (Ponomareva et al., 2020, Verbytskyi et al., 2017, Cybriwsky, 2016, Dronova \& Brunn, 2018). On the contrary, it is difficult for citizens of individual local communities to relate the low level of urban environment quality with the shortcomings in the decision-making process (Ponomareva et al., 2020). The situation in the Liko-Grad residential housing, which is the object of this study, provides evidence of such processes. As a result of the survey and analysis, it was found that the new housing was "squeezed" into the existing buildings using the practice of non-transparent decision-making. The residents of neighboring houses, representatives of educational institutions, as well as potential future residents of the housing could not influence the basic conditions of future construction. The construction of the residential housing led to a certain social polarization in the area as a whole. Today, the Liko-Grad residential housing faces a number of threats related to dense construction, a lack of multifunctionality, scarce social infrastructure, low levels of landscaping, the dominance

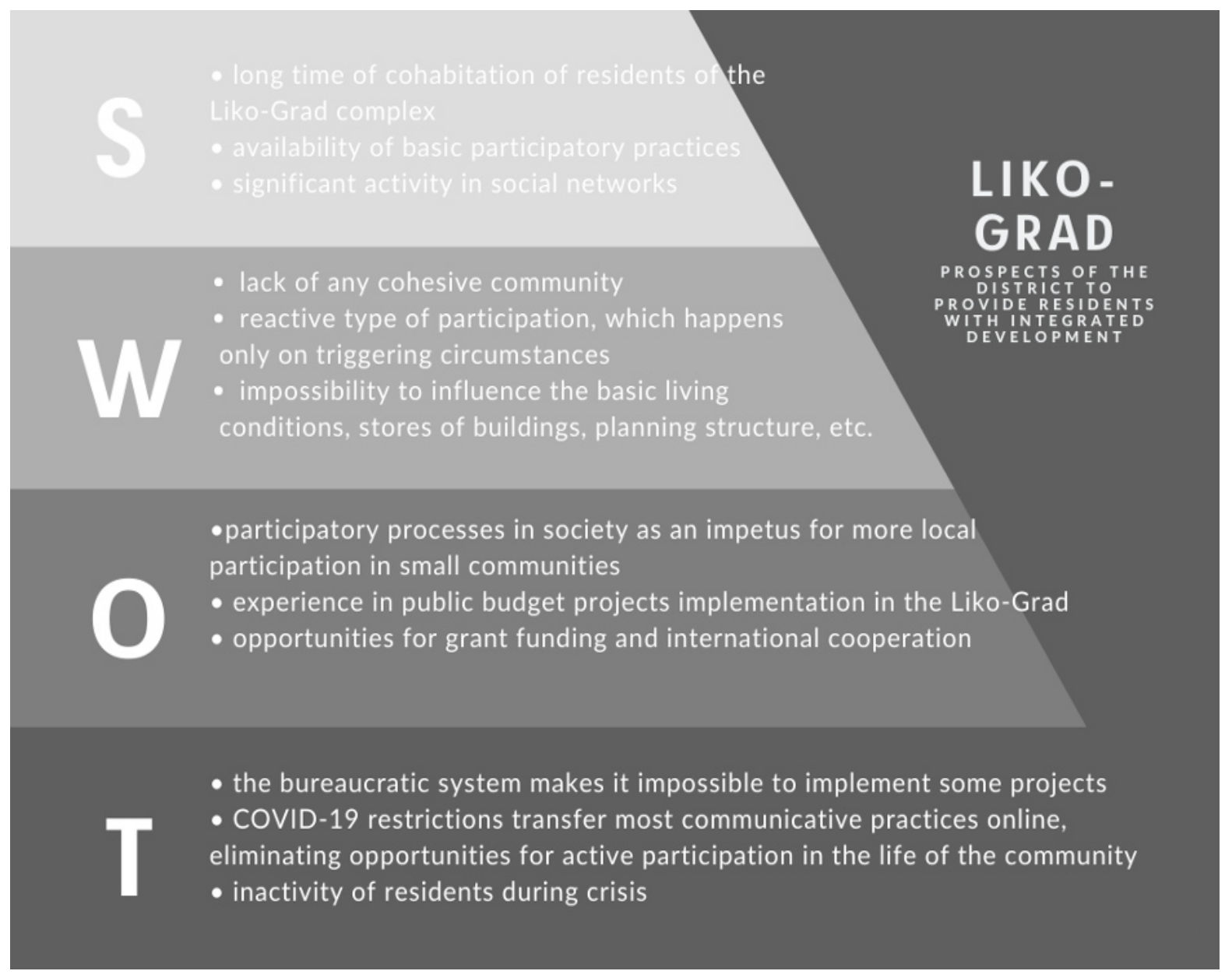

Fig. 9. Prospects of the district to provide residents with integrated development 
of chaotic parking lots, lack of bike paths and more. The needs of residents with disabilities and children are poorly met in the district's urban environment. All the above, in combination with the low level of awareness, interest and activity of local community members, indicate a low level of integration of urban development, where all spatial, sectoral and functional aspects of the territory could be coordinated and every opinion could be considered.

At the same time, it should be noted that the community of Liko-Grad is gradually beginning its own identity formation. This is evidenced with the emergence of initial participatory practices, which today represent the opportunity for development of the local democracy in the district. The community has significant potential for gradual cohesion and integration with the surrounding areas through regular good practices, active involvement in the discussion of local projects on social networks, etc. The vicinity of Taras Shevchenko National University of Kyiv can make a significant contribution to the formation of functional advantages and the local economic of the district on the basis of creative and innovative industries. Moreover, the transmission of positive experiences on the integrated inclusive communities formation on the basis of sustainable development elsewhere in Ukraine capital (Podil) and the implementation of public budget projects can be a source of inspiration for more local residents.

\section{References:}

Abukhater, A. B. E. D. (2009). Rethinking planning theory and practice: a glimmer of light for prospects of integrated planning to combat complex urban realities. Theoretical and Empirical Researches in Urban Management, 2(11), 64-79.

Al-Hamarneh, A., Margraff, J., \&Scharfenort, N. (Eds.). (2019). Neoliberale Urbanisierung: Stadtentwicklungsprozesse in der arabischen Welt. Transcript Verlag.

Arnstein, Sherry R. (1969). A Ladder of Citizen Participation. JAIP, 35(4), 216-224.

Bondar, A. Urban planning system: formal and unformal approaches. In: Analytic report Cities 2030: modernize or die. Ukrainian Institute for the Future, Interproject GmbHK. 2018, pp. 46-55. [in Ukrainian]. [Бондар А. Система міського планування: формальний та неформальний підходи. Аналітичний звіт «Міста 2030: модернізуйся, або вимирай». Український інститут майбутнього. Interproject GmbHК. 2018, с. 46-55.]

Bovron, B., Vihoda, A., Devidson, H., Mamonova, V., Sanzharovs'kyy, I., \& Fediv, I. (2008). Development and Implementation of a Strategic Plan for the Development of the Region: A practical guide. Ed: Sanzharovs'ky I. Kyiv: K.I.S. [In Ukrainian]. [Боврон Б., Вігода А., Девідсон Г., Мамонова В., Санжаровський І., Федів І. Розроблення та впровадження стратегічного плану розвитку регіону: Практичний посібник / За ред. Санжаровського I. Київ: К.І.С., 2008. 214 с.]

Brankica, M. (2018). Integrated Urban Planning in Theory and Practice. Retrieved from https://www.researchgate. net/publication/325714737_INTEGRATED_URBAN_PLANNING_IN_THEORY_AND_PRACTICE .

Chelcea, L., \& Druţă, O. (2016). Zombie socialism and the rise of neoliberalism in post-socialist Central and Eastern Europe. Eurasian Geography and Economics, 57(4-5), 521-544.

Conception of Integrated Development of Podil District of Kyiv City (2019). [In Ukrainian]. [Концепція інтегрованого розвитку Подільського району міста Києва]. Retrieved from: https://igu.org.ua/uk/node/22292

Cybriwsky, R. (2016). Kyiv, Ukraine: The city of domes and demons from the collapse of socialism to the mass uprising of 2013-2014. Amsterdam University Press.

Dronova, O., \& Brunn, S. (2018). How neoliberal globalization processes are transforming Kyiv's nodal areas. Urbani Izziv, 29(2). 96-110.

Dronova, O., \& Maruniak, E. (2019). Changing the symbolic language of the urban landscape: post-socialist transformation in Kyiv. In: Brunn S., Kehrein R. (eds), Handbook of the Changing World Language Map. Springer.

Golubchikov, O. (2016). The urbanization of transition: ideology and the urban experience. Eurasian Geography and Economics, 57(4-5), 607-623.

Golubchikov, O., Badyina, A., \& Makhrova, A. (2014). The hybrid spatialities of transition: Capitalism, legacy and uneven urban economic restructuring. Urban Studies, 51(4), 617-633.

Integrated Urban Governance. (2011). Metropolis, World Association of the Major Metropolises. First edition. Retrieved from https://www.metropolis.org/

Lawrence, D. (2002). Planning theories and environmental impact assessment. Environmental Impact Assessment Review, 20(1), 607-625.

Levchenko, O. (2019). Monitoring and Assessment of Realization of the Participative Budgets in Ukraine. In: Investments: Practice and Experience, 12, 131-136. [in Ukrainian]. [Левченко, О. В. (2019). Моніторинг та оцінювання реалізації партисипативних бюджетів в Україні. Інвестиції: практика та досвід, 12, 131-136.]

Levchenko, O., Velychko, N., \& Kovshun, L. (2018). Participatory Approach and Practices at the Community Level. A Guide for Community Activists and Anyone Interested. [In Ukrainian]. [Левченко О., Величко Н., Ковшун Л. Партисипативний підхід та практики на рівні громади. Посібник для громадських активістів та всіх зацікавлених. 2018.] Retrieved from: http://zahyst.ks.ua/wpcontent/uploads/2018/10/BOOK Zahyst Inet.pdf

Logan, J., Molotch, H. (2007). Urban fortunes: The political economy of place. University of California Press. 
LUN city platform. (2020). The Length of Queues to Kindergartens. [In Ukrainian]. [Платформа LUN-місто. Довжина черг до дитячих садків]. Retrieved from: https://misto.lun.ua/dytyachi-sadky

Lydon, M., \& Garcia, A. (2015). Inspirations and antecedents of tactical urbanism. In: Tactical Urbanism. Springer (pp. 25-62).

Matvyeyeva, N. (2017). Public Participation in Decision-Making at the Local Level. In: Sustainable Development Under the Global Challenges: Materials of All-Ukrainian Scientific-Practical Internet Conference, Kharkiv, National University of Urban Economy named after O. M. Beketov], p. 247. [in Ukrainian]. [Матвєєва, Н. М. (2017). Участь громадськості щодо прийняття рішень на місцевому рівні. Сталий розвиток в умовах глобальних викликів: матеріали Всеукраїнської науково-практичної Інтернет-конференції, Харків, Нац. Унів. Міськ. Господарства ім. О. М. Бекетова, 247.]

Mayko, T. (2017). Participation of the Territorial Community in Local Government. Current Policy Issues: a Collection of Scientific Papers, 59, 86-92. [In Ukrainian]. [Майко Т.С. Участь територіальної громади в управлінні на місцевому рівні // Актуальні проблеми політики: збірник наукових праць. 2017. Вип. 59. С. 86-92.]

Mistosite (2020). Ponomar'ova, A., Brent, Rayan D., Anisimov, O. Kyiv's new General Plan has failed. What will come next? [In Ukrainian]. [Mistosite (2020). Пономарьова А, Брент Д. Раян, Анісімов О. Генеральний план Києва провалився. Що прийде на заміну?]. Retrieved from: https://mistosite.org.ua/articles/heneralnyi-plan-kyievaprovalyvsia-shcho-pryide-na-zaminu?fbclid=IwAR3SlhqGh-7km4nHqC8IynidhUYWfXbLVGjDlsKognSYER1jsH9 16NGII-04

National Policy of Urban Development in Ukraine: What does GIZ do. (2020). [in Ukrainian]. [Національна політика міського розвитку в Україні: що робить GIZ]. Retrieved from: https://mistosite.org.ua/ru/articles/ natsionalna-polityka-miskoho-rozvytku-v-ukraini-shcho-robyt-giz

Oldenburg, R. (1999). The great good place: Cafes, coffee shops, bookstores, bars, hair salons, and other hangouts at the heart of a community. Da Capo Press.

Peck, J., Theodore, N., \& Brenner, N. (2009). Neoliberal urbanism: Models, moments, mutations. SAIS Review of International Affairs, 29(1), 49-66.

Pickett, S., Cadenasso, M., \& Grove, J. (2004). Resilient Cities: Meaning, models, and metaphor for integrated the ecological, socio-economic, and planning realms. Landscape Urban Planning, 69(4), 369-384.

Ray, S., (2012). Rapid urban change demands a theory, tools and a 'fast forward' planning - an assay. In City planning in a Hyper dynamic Age, Ed. Perm, Russia: ISOCARP.

Robinson, J., \& Parnell, I. (2011). Traveling Theory: Embracing Post-Neoliberalism through Southern Cities. In The New Blackwell Companion to the City, edited by G. Bridge and S. Watson. Chichester: Wiley-Blackwell, pp. 521-531.

Stenning, A., Smith, A., Rochovska, A., \& Swiatek, D. (2010). Domesticating Neo-liberalism: Spaces of Economic Practice and Social Reproduction in Post-socialist Cities. Oxford: Wiley-Blackwell.

Sýkora, L., \& Bouzarovski, S. (2012). Multiple transformations: Conceptualising the post-communist urban transition. Urban Studies, 49(1), 43-60.

The Law of Ukraine "On Local Self-Government in Ukraine" (1997). [In Ukrainian] [Закон України «Про місцеве самоврядування в Україні»]. Retrieved from: http://zakon.rada.gov.ua/cgi-bin/laws/main. cgi?nreg=280\%2F97-\%E2\%F0

UNDP (2002). Collection of Materials on Sustainable Development Strategy, London.

Verbytskyi, I., Hryschenko, M., \& Pyrogova, D. (2017). Research of the mechanisms of public participation in the decision-making process by Kyiv city administration. CEDOS. [In Ukrainian]. [Вербицький I., Грищенко М., Пирогова Д. (2017). Механізми участі громадян у процесі прийняття рішень у Києві: результати дослідження. CEDOS.]. Retrieved from https://cedos.org.ua/uk/articles/mekhanizmy-uchasti-hromadian-u-protsesi-pryiniattiarishen-u-kyievi-rezultaty-doslidzhennia

Wekel, J. (2016). Urban design and urban identity. In New Planning Culture in German Cities-Topics, Priorities and Processes, C. Schaber, J. Wékel and A. Zdiara (eds.), pp. 14-17. 